\title{
A specific bioelectrical impedance equation to predict body composition in Turner's syndrome
}

\author{
Uma equação de bioimpedanciometria específica para \\ predição de composição corporal na síndrome de Turner
}

Alexis D. Guedes', Bianca Bianco', Mônica V. N. Lipay', Emmanuela Q. Callou', Marise L. Castro', leda T. N. Verreschi'

1 Disciplina de Endocrinologia, Departamento de Medicina, Universidade Federal de São Paulo (Unifesp), São Paulo, SP, Brasil
Correspondence to: leda T. N. Verresch Rua Pedro de Toledo, $781,13^{\circ}$ andar 04039-032 - São Paulo, SP, Brasil ieda.verreschi@unifesp.br

Received on Aug/16/2009 Accepted on Oct/16/2009

\begin{abstract}
Introduction: Cardiovascular disease is one of the main causes for Turner syndrome (TS) mortality and the evaluation of its risk factors such as excess body fat and its distribution is considered one of the major aspects of the adult patient care. Objective: To develop and validate a specific bioelectrical impedance analysis (BIA) equation to predict body composition inTS patients. Subjects and methods: Clinical and anthropometric data, dual-energy X-ray absorptiometry (DXA) for total fat-free mass (FFM) and BIA for resistance and reactance were obtained from 50 adult TS patients. Linear regression analysis was performed with multiple clinical and BIA data to obtain a predicting equation. Results: The equation developed to estimate FFM in adult TS patients showed great consistency with DXA, elevated correlation $(r=0.974)$ and determination $\left(r^{2}=0.948\right)$ coefficients and an adequate standard error estimate $(\mathrm{SEE}=1.52 \mathrm{~kg})$. Conclusions: The specific equation developed here allowed making an adequate FFM estimate in adult TS patients. Arq Bras Endocrinol Metab. 2010;54(1):24-9
\end{abstract}

\section{Keywords}

Turner syndrome; body composition; densitometry; electric impedance

\section{RESUMO}

Introdução: A doença cardiovascular é uma das principais causas de mortalidade na síndrome de Turner (ST) e a avaliação de seus fatores de risco, como excesso e distribuição de gordura corporal, é considerada uma das principais metas da assistência às pacientes adultas. Objetivo: Desenvolver e validar uma equação de análise por bioimpedanciometria específica para estimar massa magra na ST. Sujeitos e métodos: Foram obtidos dados clínicos, antropométricos, densitometria para massa magra total e bioimpedanciometria para resistência e reactância de 50 mulheres adultas com ST. Para obter uma equação preditora, foi realizada análise de regressão linear com múltiplos dados clínicos e da bioimpedanciometria. Resultados: A equação desenvolvida para estimar massa magra na ST demonstrou grande concordância com a densitometria, elevados coeficientes de correlação $(r=0,974)$ e determinação $\left(r^{2}=0,948\right)$ e um adequado erro padrão da estimativa (SEE $=1,52 \mathrm{~kg}$ ). Conclusões: A equação desenvolvida possibilitou uma adequada estimativa da massa magra em adultas com ST. Arq Bras Endocrinol Metab. 2010;54(1):24-9

\section{Descritores}

Síndrome de Turner; composição corporal; densitometria; impedância elétrica

\section{INTRODUCTION}

$\mathrm{T}$ urner syndrome (TS) is a genetic condition, in which the complete or partial loss of one of the sex chromosomes determines the birth of individuals with female phenotype and remarkable clinical findings, such as low stature and gonadal dysgenesis (1). In the last ten years, the knowledge that cardiovascular disease stands as one of the main causes for TS mortality has intensified the evaluation of its several risk factors (2). In this context, excess body fat and its distribution have also been explored (3). 
Bioelectrical impedance analysis (BIA) is a simple, safe, inexpensive and non-invasive method to estimate fat-free mass (FFM), total body water, and fat mass (4). This method is particularly useful in determining body compartments in studies of large population samples (5). BIA is based on statistical equations developed from data collected in a given population group. The collection of anthropometric data as well as body resistance and reactance to a low-voltage electric current in the present sample guarantees that the equation developed can be applied specifically to the originally evaluated population.

Multiple equations were developed for use with diverse population groups with different body characteristics. Mathematic formulas were created for healthy populations of different ethnicities, different age groups, varied degrees of daily physical activity, and populations suffering from particular conditions and diseases $(6,7)$. However, to date no equations have been developed specifically for predicting body composition in TS patients despite its particular anthropometric characteristics (8).

Dual-energy X-ray absorptiometry (DXA) has increasingly been viewed as a laboratory method for the estimation of total body fat. Based on the concept that photon attenuation is a function of tissue composition, this method was applied as gold standard for the validation of the regression equations for BIA fat-free predictions (9).

The aim of the present study was to develop and validate a BIA equation for predicting body composition in TS patients using DXA as the reference method.

\section{SUBJECTS AND METHODS}

\section{Patients}

The study included 50 TS patients, aged 18.4 to 58.5 years, recruited from the Endocrinology Outpatient Clinic of Universidade Federal de São Paulo (Unifesp), Brazil. The TS patients selected for the present study had come to the clinic with complaints including short stature and sexual infantilism. A hormone profile of hypergonadotropic hypogonadism or an unexplained short stature led to cytogenetic evaluation. All patients included had complete epiphyseal fusion of the growth plates according to the Grewlich-Pyle atlas (10). None of them had clinically perceptible peripheral lymphedema.
The study protocol was approved by the local ethics committee. All TS patients and/or their parents gave informed consent for the study.

\section{Karyotype}

Karyotypes were determined by standard analysis of peripheral blood lymphocytes, and the number of metaphases analyzed followed the criteria adopted by Hook for detecting $8 \%$ mosaicism in 40 metaphases, with a confidence interval of $95 \%$ (11).

\section{Anthropometry}

Stature was measured three times with a fixed stadiometer, with $0.1 \mathrm{~cm}$ sensitivity, in shoeless patients. The average of three measurements was used for the analysis. Weight was measured with an electronic scale with $0.05 \mathrm{~kg}$ sensitivity, with patients wearing only undergarments and no shoes.

\section{Evaluation of body composition}

\section{Bioelectrical impedance analysis}

Resistance and reactance were measured with a singlefrequency $(50 \mathrm{kHz})$, four-channel bioimpedance analyzer (BIA 310, Biodynamics Corp., Seattle, WA, USA) according to the manufacturer's instructions. The procedure was performed with fasting patients, lying down in a supine position on a bed with non-conductive surface, with four superficial electrodes positioned on the dorsal surfaces of the right hand and foot, at the distal metacarpals and metatarsals, respectively, and between the distal prominences of the radius and the ulna at the wrist, and the medial and lateral malleoli at the ankle.

\section{Dual-energy X-ray absorptiometry}

A DXA scanner (Hologic QDR 4500C, Hologic Inc, Bedford, MA, USA) was used for whole-body scan composition evaluation of the total and segmented soft section (arms, legs and torso).

\section{Statistical analysis}

Descriptive statistics was used for age, weight, height, body mass index (BMI), resistance and reactance parameters (BIA), fat-free body mass, total and perceptual fat (DXA). With the data obtained by DXA as reference, stepwise multiple regression analysis was used to develop a predicting equation of the FFM for BIA. Pre- 
dicting variables gathered through BIA parameters and anthropometry were progressively added to the equation model, in order to obtain the highest level of correlation and reduce the estimate margin of error. Bland and Altman analysis was used to assess the agreement between the FFM estimated by the regression equation developed and the one obtained by DXA. This analysis consists of establishing the joint mean of the difference between the results of the measurements obtained by both instruments used, followed by plotting the difference of each case individually. The BIAS, the confidence interval for the agreement limit and finally the validity of the instrument studied were evaluated from the interval between two standard errors above and two standard errors below the mean difference (12).

Three validated equations to estimate FFM in populations without TS were applied to the present study sample in order to compare the FFM data obtained by DXA. The determination coefficient, the BIAS and the limits of agreement by the Bland and Altman analysis were used to compare the FFM results and differences from DXA obtained with the equations of Heitmann (13) $\left[0.279 \mathrm{x}\right.$ stature ${ }^{2} /$ resistance $\left(\mathrm{cm}^{2} / \mathrm{ohms}\right)+0.181 \mathrm{x}$ weight $(\mathrm{kg})+0.231 \mathrm{x}$ stature $(\mathrm{cm})-0.077 \mathrm{x}$ age (years) -14.94]; Segal and cols. (14) [0.00108 x stature $(\mathrm{cm})$ - $0.0209 \mathrm{x}$ resistance $(\mathrm{ohms})+0.23199 \mathrm{x}$ weight $(\mathrm{kg})$ $0.06777 \mathrm{X}$ age (years) +14.59453 ]; Kyle and cols. (15) $\left[-4.104+0.518 \times\right.$ stature $^{2} /$ resistance $\left(\mathrm{cm}^{2} /\right.$ ohms $)+$ $0.231 \times$ weight $(\mathrm{kg})+0.13 \times$ reactance $(\mathrm{ohms})]$ and of this study. The significance level was set at $\mathrm{p}<0.05$.

\section{RESULTS}

TS patients karyotypes were distributed as shown in table 1

The predicting equation developed to estimate the FFM of the 50 TS patients through BIA is described in table 2 .

Evaluation of the relative importance of each variable individually and associated with the other variables in the equation is presented in table 3.

Bland and Altman's analysis evaluating the BIA formula applied to the full sample, and the scatter plot illustrating the correlation with the DXA findings are shown in figure 1. As per Bland and Altman's analysis, the mean difference and standard deviation of the FFM obtained by DXA and BIA was 0.06 and $1.48 \mathrm{~kg}$, respectively, the agreement for the limit interval (2SD) being between +3 and $-2.9 \mathrm{~kg}$.
Table 1. Cytogenetic characterization of the TS patients studied

\begin{tabular}{lc}
\hline Karyotype & n \\
\hline $45, X$ & 36 \\
$45, X / 46, X X$ & 3 \\
$45, X / 46, X$, , (X)(q10) & 3 \\
$45, X / 46, X Y$ & 1 \\
$45, X / 46, X X,+$ mar & 1 \\
$45, X / 46, X X, p+$ & 1 \\
$45, X / 47, X X X$ & 1 \\
$45, X / 46, X X$, add $(X)(q 22)$ & 1 \\
$45, X / 46, X X$, add $(15)(p 11)$ & 1 \\
$46, X$, derX(p11.2) & 1 \\
$46, X$, idicX(q10) & 1 \\
Total & 50 \\
\hline
\end{tabular}

Table 2. Anthropometric data, BIA and DXA results from 50 TS patients studied

\begin{tabular}{lccc}
\hline Variable & Median & Minimum & Maximum \\
\hline Age (years) & 24.7 & 18.3 & 58.5 \\
Weight $(\mathrm{kg})$ & 51.9 & 30.2 & 113.0 \\
Stature $(\mathrm{m})$ & 1.43 & 1.26 & 1.61 \\
BMl $\left(\mathrm{kg} / \mathrm{m}^{2}\right)$ & 24.4 & 16.6 & 43.4 \\
Resistance & 652.5 & 451.0 & 815.0 \\
Reactance & 76.5 & 45.0 & 131.0 \\
DXA total fat (g) & $16,925.0$ & $8,448.5$ & $54,481.0$ \\
DXA fat-free mass (g) & $33,472.3$ & $21,713.1$ & $58,964.8$ \\
Fat percentage (\%) & 33.0 & 21.3 & 48.0 \\
\hline
\end{tabular}

BMI: body mass index; DXA: dual-energy $\mathrm{X}$-ray absorptiometry.

Table 3. Relative importance of BIA variables in predicting FFM in Turner syndrome patients

\begin{tabular}{lcccc}
\hline Variable & $\mathbf{r}$ & $\mathbf{r}^{2}$ & SEE & p-value \\
\hline$S^{2} / R$ & 0.86 & 0.739 & 3.328 & $<0.001$ \\
$W$ & 0.942 & 0.887 & 2.189 & $<0.001$ \\
$S$ & 0.704 & 0.496 & 4.630 & $<0.001$ \\
$S^{2} / R+W$ & 0.966 & 0.933 & 1.701 & $<0.001$ \\
$S^{2} / R+W+S$ & 0.974 & 0.948 & 1.519 & $<0.001$ \\
\hline
\end{tabular}

$S^{2} / R$ : stature2/resistance; W: weight; $S$ : stature; $r$ : correlation coefficient; $r^{2}$ : determination coefficient; SEE: standard error estimation.

The determination coefficient and agreement analyzed by Bland and Altman's method for the FFM of TS patients obtained by DXA and the estimates obtained with the regression equation for BIA of this study and with equations from three other studies are presented in table 4 . 
FAT-FREE MASS by BIA $(\mathrm{g})$

$=-11.068+0.307 \times S^{2} / R\left(\mathrm{~cm}^{2} / 0 h m s\right)+0.286 \mathrm{X}$ weight. $(\mathrm{kg})+0.14 \mathrm{X}$ stature. $(\mathrm{cm})$

FFM DXA measured $($ mean $\pm S D)=33.82 \pm 6.45 \mathrm{~kg}$

FFM BIA estimated $($ mean \pm SD) $=33.89 \pm 6.29 \mathrm{~kg} r=0.974$, SEE $=1.52 \mathrm{~kg}$ $\mathrm{N}=50$

$S^{2} / R=$ stature $2 /$ resistance; $r$ = correlation coefficient; $S E E$ = standard error estimation.

Figure 1. BIA-based FFM estimation equation and FFM mean ( \pm SD) measured by DXA and estimated by BIA in the TS sample studied.

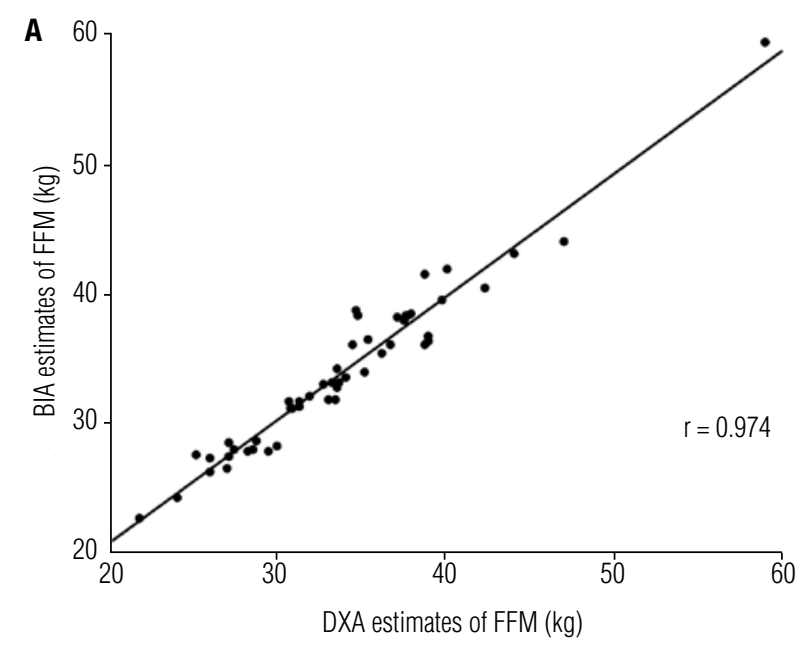

B

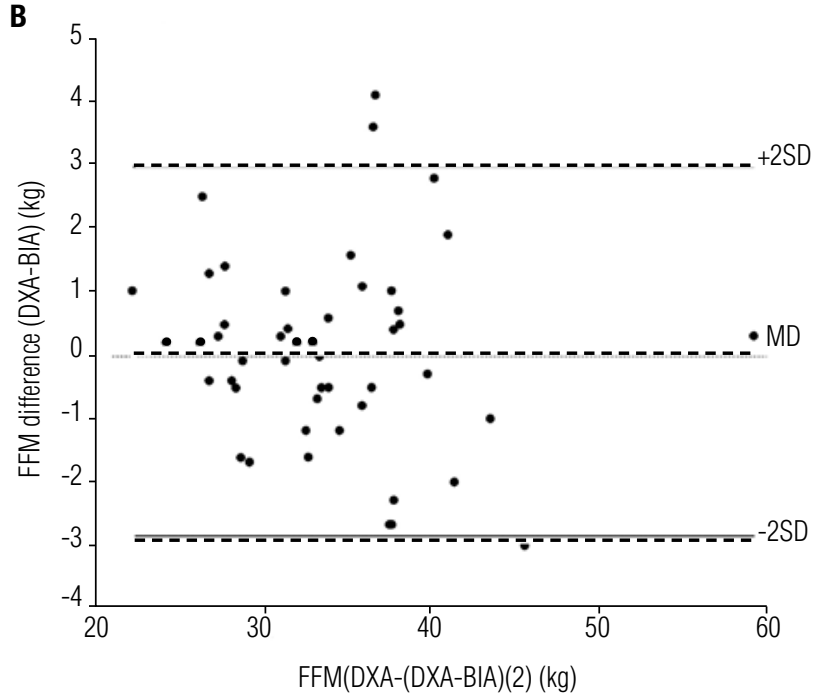

$\mathrm{MD}=$ Mean of the joined difference of FFM by DXA and BIA

Figure 2. Scatter plot illustrating the BIA correlation with the DXA(A). Bland and Altman analysis evaluating the BIA formula applied to the full sample (B).

\section{DISCUSSION}

Previous studies that evaluated body composition in adult women with TS and estimated the percentage of body fat distribution and FFM have utilized several methods and equipment. There have been evaluations performed by skinfold measurement $(16,17)$, ultraso-
Table 4. Determination coefficient, agreement limits and BIAS of the sample analysis with the present study equation and three other ones

\begin{tabular}{lccc}
\hline Studies & BIAS $^{*}(\mathbf{k g})$ & Agreement limits $\mathbf{( k g )}$ & $\mathbf{r}^{\mathbf{2}}$ \\
\hline Present study & 0.06 & -2.89 to +3.02 & 0.948 \\
Segal and cols. (14) & -0.37 & -3.89 to +3.15 & 0.925 \\
Heitmann (13) & 0.67 & -3.83 to +5.18 & 0.889 \\
Kyle and cols. (15) & -1.35 & -6.48 to +2.56 & 0.848 \\
\hline
\end{tabular}

$r^{2}$ : determination coefficient.

${ }^{*}$ Mean difference between the FFM measured by DXA and using the regression equations for BIA.

nography (18), DXA $(19,20)$, BIA $(21,22)$ and magnetic resonance imaging (23). If, on the one hand they produce high-quality information on the other some of these instruments are relatively expensive and have little mobility (24). BIA is characterized by being simple to perform, low-cost and of good mobility which singles it out for population studies which demand large samples and may require the displacement of researchers for field data collection. Previous studies which used BIA for body composition evaluation in TS did so using equations developed for normal populations or equations not made freely available by the bioelectrical impedance analyzer manufacturers $(25,26)$. Based on multiple linear regression models the development of predicting equations is specific for the populations from which the original samples were collected. Population groups with particular characteristics determine the need for specific mathematic formulae. Knowing that BIA is based on the theoretical relationship between the volume of the organic conductor and its resistance to an established electric current and that, putting it simply, volume depends on the length and transversal area of that conductor, both height and other anthropometric body characteristics definitely influence its measuring (27). TS patients have physical characteristics that distinguish them from normal women. The differences in body proportions are remarkable. These patients have a low arm span, short stature and high bi-iliac diameters compared to normal women (28). These particular anthropometric measurements justify the need for specific BIA equations developed for this population group.

Considering that life expectancy of TS patients is reduced mainly due to cardiovascular disease and that the presence of risk factors associated to obesity is more prevalent than in women without this genetic alteration (29), validation of specific body composition analysis instruments is clearly needed.

In this study, performed in an adult population with TS we developed a predicting equation for FFM to be 
used with BIA and compared it with three previously developed equations; however, appropriate for normal populations (without TS).

As in several equation validation studies for BIA, here the interaction of the ratio established between the square stature and resistance $\left(S^{2} / \mathrm{R}\right)$ and anthropometric data defined an equation with a high degree of agreement with the method used for comparison (DXA). In this equation, weight gave the greatest contribution among the variables studied followed by the $\mathrm{S}^{2} / \mathrm{R}$ ratio. Combined they could explain more than $90 \%$ of the FFM variance $\left(r^{2}=0.933\right)$. Stature was the only other variable that significantly contributed to the equation with increase of the multiple regression determination coefficient and with reduction of the standard estimation error $\left(r^{2}=0.948\right.$, SEE 1.519).

Regarding the size of the study sample, it can be considered adequate for the development of BIA equations taking into account prevalence of TS in the population, 1:2500 to $1: 3000$ of live born girls, and their particular body characteristics (30). Nevertheless, the number of participants limited the possibility of validating the equation in a TS sample different from the one used to build the equation. This procedure could have enhanced the power of the developed equation.

In the TS sample studied, Bland and Altman's analysis used to compare FFM obtained by DXA with that obtained using the regression equation developed by us, and also those previously validated by Segal and cols. (14), Heitmann (13), and Kyle and cols. (15), an acceptable agreement was demonstrated for all comparisons made. As expected, the limits for the agreement and mean differences between FFM measured by DXA and that predicted by BIA were lower for the equation originated from the sample of TS women of this study. However, only validation of the equation developed in the present study in independent samples of TS women can determine if it is actually superior to other previously developed equations.

\section{CONCLUSION}

To the best of our knowledge, the present study is the first to validate a specific equation for adult TS patients. Additional studies are necessary to confirm the validity of this equation.

Acknowledgments: this project was supported by Fundação de Amparo à Pesquisa do Estado de São Paulo (Fapesp), Grant $n^{\circ}$ 2008/03597-0.
Disclosure: no potential conflict of interest relevant to this article was reported.

\section{REFERENCES}

1. Lippe B. Turner syndrome. Endocrinol Metab Clin North Am. $1991 ; 20(1): 121-52$.

2. Gravholt $\mathrm{CH}$, Juul S, Naeraa RW, Hansen J. Morbidity in Turner syndrome. J Clin Epidemiol. 1998;51(2):147-58.

3. Gravholt $\mathrm{CH}$, Hjerrild BE, Mosekilde L, Hansen TK, Rasmussen LM, Frystyk J, et al. Body composition is distinctly altered in Turner syndrome: relations to glucose metabolism, circulating adipokines, and endothelial adhesion molecules. Eur J Endocrinol. 2006;155(4):583-92.

4. Houtkooper LB, LohmanTG, Going SB, Howell WH. Why bioelectrical impedance analysis should be used for estimating adiposity. Am J Clin Nutr. 1996;64(3 Suppl):436S-48S.

5. Chumlea WC, Guo SS, Kuczmarski RJ, Flegal KM, Johnson CL, Heymsfield SB, et al. Body composition estimates from NHANES III bioelectrical impedance data. Int J Obes Relat Metab Disord. 2002;26(12):1596-609.

6. Demura S, Yamaji S, Goshi F, Kobayashi H, Sato S, Nagasawa Y. The validity and reliability of relative body fat estimates and the construction of new prediction equations for young Japanese adult males. J Sports Sci. 2002;20(2):153-64.

7. Horie LM, Barbosa-Silva MC, Torrinhas RS, de Mello MT, Cecconello I, Waitzberg DL. New body fat prediction equations for severely obese patients. Clin Nutr. 2008;27(3):350-6.

8. Baldin AD, Armani MC, Morcillo AM, Lemos-Marini SH, Baptista MT, Maciel-Guerra AT, et al. Body proportions in a group of Brazilian patients with Turner syndrome. Arq Bras Endocrinol Metab. 2005;49(4):529-35.

9. Plank LD. Dual-energy X-ray absorptiometry and body composition. Curr Opin Clin Nutr Metab Care. 2005;8(3):305-9.

10. Greulich WW, Pyle SI. Radiographic atlas of skeletal development of the hand and wrist. 2nd ed. Stanford: Stanford University Press; 1959;

11. Hook EB. Exclusion of chromosomal mosaicism: tables of $90 \%$, $95 \%$ and $99 \%$ confidence limits and comments on use. Am J Hum Genet. 1977;29(1):94-7.

12. Bland JM, Altman DG. Statistical methods for assessing agreement between two methods of clinical measurement. Lancet. 1986;1(8476):307-10.

13. Heitmann BL. Prediction of body water and fat in adult Danes from measurement of electrical impedance. A validation study. Int J Obes. 1990;14(9):789-802.

14. Segal KR, Van LM, Fitzgerald PI, Hodgdon JA, Van Itallie TB. Lean body mass estimation by bioelectrical impedance analysis: a four-site cross-validation study. Am J Clin Nutr. 1988;47(1):7-14.

15. Kyle UG, Genton L, Slosman DO, Pichard C. Fat-free and fat mass percentiles in 5225 healthy subjects aged 15 to 98 years. Nutrition. $2001 ; 17(7-8): 534-41$.

16. Delgado JA, Trahms CM, Sybert VP. Measurement of body fat in Turner syndrome. Clin Genet. 1986;29(4):291-7.

17. Hanaki K, Ohzeki T, Ishitani N, Motozumi H, Matsuda-Ohtahara $\mathrm{H}$, Shiraki K. Fat distribution in overweight patients with UllrichTurner syndrome. Am J Med Genet. 1992;42(4):428-30.

18. Ohzeki T, Hanaki $\mathrm{K}$, Motozumi H, Ohtahara $\mathrm{H}$, Urashima $\mathrm{H}$, Shiraki $\mathrm{K}$. Assessment of subcutaneous fat using ultrasonography in the Ullrich-Turner syndrome. Am J Med Genet. 1993;46(4):450-2.

19. Corrigan EC, Nelson LM, Bakalov VK, Yanovski JA, Vanderhoof $\mathrm{VH}$, Yanoff LB, et al. Effects of ovarian failure and X-chromosome 
deletion on body composition and insulin sensitivity in young women. Menopause. 2006;13(6):911-6.

20. Gravholt $\mathrm{CH}$, Hjerrild BE, Mosekilde L, Hansen TK, Rasmussen LM, Frystyk J, et al. Body composition is distinctly altered in Turner syndrome: relations to glucose metabolism, circulating adipokines, and endothelial adhesion molecules. Eur $\mathrm{J}$ Endocrinol. 2006;155(4):583-92.

21. Gravholt $\mathrm{CH}$, Weis NR. Reference values for body proportions and body composition in adult women with Ullrich-Turner syndrome. Am J Med Genet. 1997;72(4):403-8.

22. Gravholt $\mathrm{CH}$, Naeraa RW, Nyholm B, Gerdes LU, Christiansen $E$, Schmitz $O$, et al. Glucose metabolism, lipid metabolism, and cardiovascular risk factors in adult Turner's syndrome. The impact of sex hormone replacement. Diabetes Care. 1998;21(7):1062-70.

23. Ostberg JE, Thomas EL, Hamilton G, Attar MJ, Bell JD, Conway GS. Excess visceral and hepatic adipose tissue in Turner syndrome determined by magnetic resonance imaging: estrogen deficiency associated with hepatic adipose content. J Clin Endocrinol Metab. 2005;90(5):2631-5.
24. Lee SY, Gallagher D. Assessment methods in human body composition. Curr Opin Clin Nutr Metab Care. 2008;11(5):566-72.

25. Gravholt CH, Naeraa RW, Nyholm B, Gerdes LU, Christiansen E, Schmitz O, et al. Glucose metabolism, lipid metabolism, and cardiovascular risk factors in adultTurner's syndrome. The impact of sex hormone replacement. Diabetes Care. 1998;21(7):1062-70.

26. Ostberg JE, Thomas EL, Hamilton G, Attar MJ, Bell JD, Conway GS. Excess visceral and hepatic adipose tissue in Turner syndrome determined by magnetic resonance imaging: estrogen deficiency associated with hepatic adipose content. J Clin Endocrinol Metab. 2005;90(5):2631-5.

27. Dehghan M, Merchant AT. Is bioelectrical impedance accurate for use in large epidemiological studies? Nutr J. 2008;7:26.

28. Gravholt $\mathrm{CH}$, Weis NR. Reference values for body proportions and body composition in adult women with Ullrich-Turner syndrome. Am J Med Genet. 1997;72(4):403-8.

29. Elsheikh M, Dunger DB, Conway GS, Wass JA. Turner's syndrome in adulthood. Endocr Rev. 2002;23(1):120-40.

30. Sybert VP, McCauley E. Turner's syndrome. N Engl J Med. 2004;351(12):1227-38. 